\title{
The Association between Obesity and Premenopausal Breast Cancer According to Intrinsic Subtypes - a Systematic Review
}

\author{
Assoziation zwischen Adipositas und intrinsischen Subtypen \\ beim prämenopausalem Mammakarzinom - eine systematische \\ Übersichtsarbeit
}

(C) (P) $\ominus$

Authors

Luz Angela Torres-de la Roche ${ }^{1,2}$, Isabell Steljes ${ }^{1}$, Wolfgang Janni ${ }^{3}$, Thomas W. P. Friedl ${ }^{3}$, Rudy Leon De Wilde ${ }^{2}$

Affiliations

1 Human Medicine, Carl von Ossietzky Universität

Oldenburg, Oldenburg, Germany

2 Gynecology, Pius-Hospital Oldenburg, Oldenburg, Germany

3 Frauenklinik, Klinikum der Universität Ulm, Ulm, Germany

Key words

hormone receptor, premenopause, breast neoplasms, receptors, obesity, risk factors

Schlüsselwörter

Hormonrezeptor, Prämenopause, Brusttumoren, Rezeptoren, Adipositas, Risikofaktoren

received $\quad 16.10 .2019$

revised 6.4 .2020

accepted 27.4.2020

Bibliography

DOI https://doi.org/10.1055/a-1170-5004

Geburtsh Frauenheilk 2020; 80: 601-610 @ Georg Thieme

Verlag KG Stuttgart · New York | ISSN 0016-5751

Correspondence

Dr. Rudy Leon De Wilde

Pius-Hospital, Klinik für Frauenheilkunde,

Geburtshilfe und Gynäkologische Onkologie

Georgstraße 12, 26121 Oldenburg, Germany

Rudy-Leon.Dewilde@Pius-Hospital.de

\section{ABSTRACT}

Introduction Obesity is a well-established risk factor for postmenopausal hormone-receptor positive breast cancer. The relationship between premenopausal breast cancer intrinsic subtypes and obesity is not completely elucidated; therefore, this systematic review was conducted to give an overview about the existing evidence.
Methods This review followed the PRISMA Statement for Systematic Reviews and Meta-analyses. Full electronic search was conducted in PubMed and Orbis for articles published in English between January 2008 and June 2018. The literature search was performed in June 2018 using search strings that combined the Medical Subject Headings (MeSH terms) keywords and/or text words in any field were used: "body mass index" (BMI) OR obesity OR overweight AND premenopausal breast cancer.

Results 391 articles were found to be eligible, of which ultimately 21 were included comprising a total of 55580 breast cancer patients. $45 \%$ were case-control studies, $35 \%$ were single cohort studies, $15 \%$ were cohort studies, two were crosssectional studies, one was a multicenter-study and one was a pooled analysis. The evidence shows a tendency for an increased risk for the more aggressive triple negative breast cancer subtype in obese premenopausal women and a decreased risk for less aggressive tumor subtypes such as the luminal A subtype. The evidence is limited by small sample sizes for triple negative and HER2-positive subtypes in severely obese patients.

Conclusion Higher BMI might influence aggressive tumor characteristics among premenopausal women and has divergent impacts on the risk of different breast cancer subtypes. Further research is needed to confirm these results and to evaluate potential pathophysiologic mechanisms for the relationship between obesity and aggressive premenopausal breast cancer subtypes.

\section{ZUSAMMENFASSUNG}

Einleitung Übergewicht ist ein bekannter Risikofaktor für postmenopausalen hormonrezeptorpositiven Brustkrebs. Der Zusammenhang zwischen prämenopausalen intrinsischen Mammakarzinom-Subtypen und Übergewicht ist aber noch nicht ganz geklärt. Es wurde daher eine systematische Literaturrecherche durchgeführt, um einen Überblick der existierenden Evidenz zu bekommen. 
Methoden Diese Literaturrecherche wurde gemäß den PRISMA-Vorgaben zu systematischen Übersichten und Metaanalysen durchgeführt. In den Datenbanken PubMed und Orbis wurde eine elektronische Suche nach englischsprachigen Artikeln, die zwischen Januar 2008 und Juni 2018 veröffentlicht wurden, durchgeführt. Die Literaturrecherche wurde im Juni 2018 vorgenommen unter Verwendung einer Kombination von MeSH (Medical Subject Headings) Suchbegriffen und „und/oder“ Worten in allen Feldern wie folgt: „body mass index“ (BMI) OR „obesity“ OR „overweight“ AND „premenopausal breast cancer“.

Ergebnisse Insgesamt fanden sich 391 geeignete Publikationen, von denen schließlich 21 Studien, die insgesamt 55580 Brustkrebspatientinnen einschlossen, ausgewählt wurden. Von den ausgewählten Studien waren 45\% Fallkontrollstudien, 35\% einfache Kohortenstudien und 15\% Kohortenstudien. Es waren auch 2 Querschnittsstudien, eine multi- zentrische Studie und eine gepoolte Analyse darunter. Die durch die Recherche gewonnene Evidenz zeigt, dass adipöse prämenopausale Frauen ein tendenziell höheres Risiko für aggressivere triple-negative Brustkrebs-Subtypen und ein geringeres Risiko für weniger aggressive Subtypen wie Luminal-ATumoren aufweisen. Die kleine Fallzahl an stark adipösen Patientinnen mit triple-negativen und HER2-positiven Subtypen schränkt jedoch die Aussagekraft der Evidenz ein.

Schlussfolgerung Ein höherer BMI könnte einen Einfluss auf aggressive Tumoreigenschaften bei prämenopausalen Frauen haben und hat unterschiedliche Auswirkungen auf das Risiko für verschiedene Brustkrebs-Subtypen. Es werden weitere Studien benötigt, um diese Ergebnisse zu bestätigen und die möglichen pathophysiologischen Mechanismen für die Beziehung zwischen Adipositas und aggressiven prämenopausalen Brustkrebs-Subtypen zu ermitteln.

\section{Introduction}

Overweight and obesity are the consequences of abnormal or excessive accumulation of body fat that present a risk to health. According to $\mathrm{WHO}$, overweight and obesity are defined as a Body Mass Index (BMI) (weight [kilograms]/height $\left[\mathrm{m}^{2}\right]$ ) from $\geq 25-$ $29.9 \mathrm{~kg} / \mathrm{m}^{2}$ and $\geq 30 \mathrm{~kg} / \mathrm{m}^{2}$, respectively [1].

Obesity is a major public health problem, especially for developed countries, and has been associated with cancer risk and mortality [2]. The worldwide obesity epidemic has serious consequences for cancer incidence and cancer-related mortality [3,4]. In 2016, 650 million adults aged 18 years and older worldwide were obese (men 11\%, women 16\%) and about two-thirds of men and half of women in Germany were overweight with the prevalence increasing $[5,6]$.

In women, obesity is associated with endometrial (RR 1.59), gallbladder (RR 1.59), esophageal adenocarcinoma (RR 1.51), renal cancers (RR 1.34) and postmenopausal breast cancer (RR 1.12) [2]. More specifically, randomized controlled trials, observational studies, meta-analyses, and reviews show that overweight and obesity increases the risk for hormone receptor positive breast cancer in postmenopausal women [2, 7]. In contrast, some evidence has indicated a reduced risk of hormone receptor positive breast cancer in obese premenopausal women, though when diagnosed these cases have been associated with a worse prognosis $[7-11]$.

Further evidence shows that obesity in women is related to the prognosis of breast cancer patients, obese women with premenopausal breast cancer have a higher incidence of larger tumors, a shorter overall survival, and higher BMI indexes were associated with an increase in mortality $[8,10]$. Other studies also reported that higher BMI in the premenopausal period is significantly associated with characteristics of more aggressive tumor phenotypes, such as larger tumor size, higher cell proliferation, more frequent lymph node metastasis and presence of vascular infiltration [1013].
The mechanisms by which obesity induces tumorigenesis vary by cancer type and are not fully understood yet. However, some possible pathophysiologic mechanisms for carcinogenesis have been proposed. Adipose tissue is an active endocrine and metabolic organ that releases free fatty acids and hormones such as leptin, adiponectin, resistin and tumor necrosis factor alpha (TNF- $\alpha$ ). The increased release of leptin, TNF- $\alpha$ and free fatty acids leads to development of insulin resistance and chronic hyperinsulinemia. This results in increased circulating insulin and insulinlike-growth-factor levels, which promote cellular proliferation and inhibit apoptosis. Especially hyperinsulinemia leads to a reduction of hepatic synthesis of sex-hormone-binding globulin (SHBG). Moreover, adipose tissue produces aromatase and $17 \beta$ hydroxysteroid dehydrogenase (17 $\beta-\mathrm{HSD})$. Aromatase leads to an increased conversion of androgens $\Delta 4$-androstendione $(\triangle 4 \mathrm{~A})$ and testosterone $(T)$ into the estrogens estrone (E1) and estradiol (E2) in obese individuals. $17 \beta$-HSD converts $\triangle 4 \mathrm{~A}$ and $\mathrm{E} 1$ into the active hormones E2 and T. Combined with decreased SHBG levels, this leads to increased bioavailable fractions of E2 and $T$, which bind to estrogen and androgen receptors and promote cellular proliferation and inhibit apoptosis, especially in tissues like breast epithelium [9].

There are different classifications for breast cancer. The intrinsic subtypes include four main subgroups: the estrogen receptor $(E R)$, progesterone receptor (PR) and human epidermal growth factor 2 (HER2) negative tumors, defined as triple negative breast cancer (TNBC) (ER-/PR-/HER-); the hormone receptor negative but HER2 positive tumors (ER-/PR-/HER2+); the hormone receptor positive but HER2 negative expression (ER and/or PR positive/ HER2-), defined as luminal A tumor, and the hormone receptor positive luminal $B$ tumor, ER and/or PR positive, which is mostly subdivided into HER2 + or HER2- subtype $[14,15]$.

As at the moment only conflicting findings from meta-analyses or reviews focusing on obesity and premenopausal breast cancer risk without focusing on intrinsic subtypes are available, the purpose of this study is to perform a review of literature to summarize the current state of knowledge in regard to obesity as a risk 
factor for the different intrinsic subtypes of breast cancer in premenopausal women. The specific research questions were: 1) How much is known about obesity in premenopausal women as a risk factor for specific breast cancer subtypes? And 2) Are there differences with regard to the intrinsic subtypes between obese and non-obese premenopausal women with breast cancer?

\section{Methods}

\section{Search strategy}

The literature research was implemented according to PRISMAStatement ("Preferred Reporting Items for Systematic Reviews and Meta-Analyses"), an evidence-based set of items from a panel of experts for good scientific practice for reporting systematic reviews and meta-analyses [16]. The search was conducted in June of 2018.

For searching potentially relevant literature, a two-tiered approach was followed. First, general reviews, guidelines and metaanalysis were consulted to define more focused and specific search terms. Eligible studies were identified by performing a search in the "PubMed" and "Orbis" (database from University of Oldenburg) databases from 2008 to 2018 . For searching relevant literature on obesity and the risk of different subtypes of breast cancer in premenopausal women the following Medical Subject Headings (MeSH), keywords and/or text words in any field were used: "body mass index" (BMI) OR obesity OR overweight, AND premenopausal breast cancer. The search included full-text publications in English-language only. As the Orbis database includes the PubMed database, PubMed was excluded for Orbis literature search to reduce duplicates. Papers were assessed through titles and abstracts to determine relevance and suitability for inclusion. In order to obtain additional studies, review articles and metaanalyses were screened.

\section{Inclusion and exclusion criteria}

Only full text articles originally published in English between 2008 and 2018 or "milestone articles", defined as articles that were cited by more than five of the included articles within the past ten years, were taken into consideration. Studies were eligible for inclusion/exclusion according to the following criteria:

\section{Inclusion criteria}

- Articles should be clinical trials, cohort studies, single cohort studies, case-control studies or nested-case-control studies

- Studies should report data on BMI

- Articles should provide subgroup analysis of premenopausal and postmenopausal women or only include premenopausal women

- Articles should specify breast cancer subtypes or at least ER and PR statuses

\section{Exclusion criteria}

- Articles that used only other anthropometric measurements than BMI, such as waist-to-hip-ratio (WHR), waist-circumference (WC) or only height, or studies that reported only data on weight gain or weight in childhood or birth weight.
- Studies limited to special populations like BRCA1/2 mutation carriers, only men or only postmenopausal women.

- Articles that reported results for all breast cancer without distinguishing between premenopausal and postmenopausal women and subtypes.

- Articles that focused on breast cancer survival and recurrence in correlation to overweight or obesity.

\section{Quality assessment and data extraction}

Several variables contribute to the quality of observational studies and were assessed for each study. These include information about characteristics and size of study sample, clarity of definitions used (definition for BMI, definition for subtypes), clarity of presentation of the results.

The following data were collected from each study: first author, publication year, country of study, population, type of study, number of cases with premenopausal breast cancer, age range, period of enrolment, methods of BMI measurement (self-reported or standardized measure), and reported immunohistochemical marker.

\section{Results}

The literature search for obesity and premenopausal breast cancer risk according to intrinsic subtypes identified 410 citations of which 19 were identified by hand search. After duplicates were removed, 391 abstracts and titles were screened for eligibility. 281 records were excluded, because they did not meet the inclusion criteria. 110 candidate papers were screened and further reviewed in full-text for eligibility. 90 of these full-text articles were excluded for the following reasons: 35 had no subdivision into subtypes, 16 have not distinguished between pre-and postmenopausal women, 12 focused on breast cancer prognosis, survival or recurrence rate in obese women, 10 had no original data (such as same study cohort, pooled analysis, review or report), 8 focused on diet, physical activity, weight gain or weight change, 7 used other measurements for weight than BMI or used other BMI classifications, one study did not describe the study population completely and one article was retracted. Thus 21 studies were finally included in this systematic review ( $\triangleright$ Fig. 1 ).

\section{Study characteristics}

The included articles were published between 2008 and 2018; one paper was added as a milestone article from $2007.45 \%$ of the papers were case-control studies, $35 \%$ were single cohort studies, $15 \%$ were cohort studies, two were cross-sectional studies, one study was a multi-center study and one was a pooled analysis. The studies involved a total of 55580 patients.

Seven of the studies were conducted in USA, five were from Europe (two from Italy, one from France, one from Poland and one from Germany), and seven were from Asia (three from China, two from Japan, one from India and one from Turkey). $25 \%$ had a sample size $\geq 1000$, 35\% had 500-1000 participants, 35\% had 200-500 participants and 5\% had a study size between 100 and 200 participants. The pooled analysis included 35568 cases from different studies that were not additionally included in our review. 


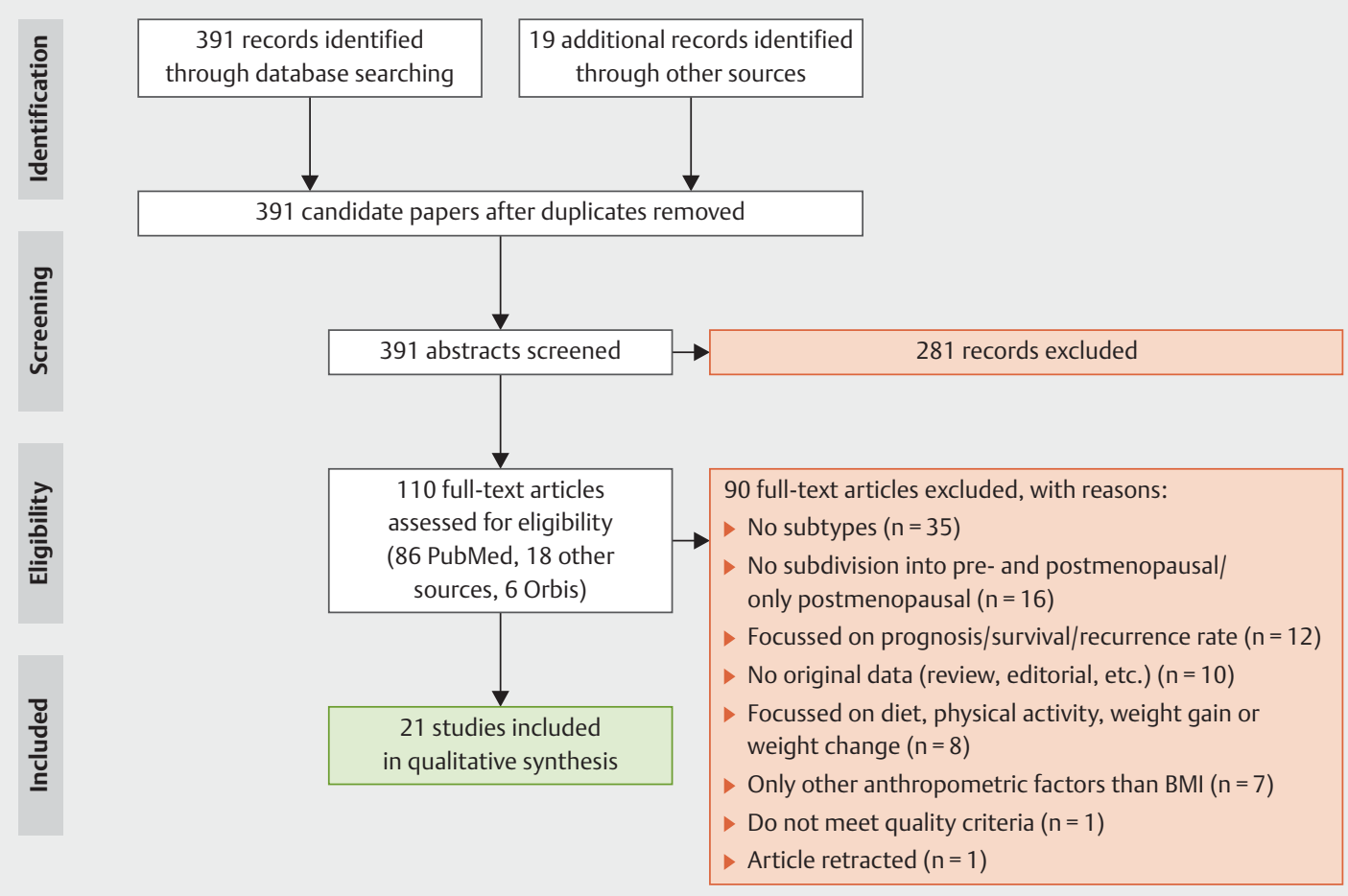

- Fig. 1 Identification, review and selection of studies included in the systematic review, according to PRISMA [16], published between January 2008 and June 2018.

The study characteristics for each study are summarized in - Table 1.

\section{ER/PR positive and negative breast cancer risk}

Eleven studies, comprising 46700 participants, reported data on ER and PR status, of which six were case-control studies, two were cohort studies, two were single cohort studies and one was a pooled analysis. Regarding the risk of ER/PR positive BC, three of the case-control studies showed no significant association [18$20]$, two studies reported a decreased risk $[17,24]$, whereas one showed an increased risk [21]. Regarding the risk of ER/PR negative $B C$, four of the case-control studies showed no significant association [17-20,22,23], one reported a decreased risk [24] and one demonstrated an increased risk [21,25].

The population-based case-control study by John et al. [17] investigated differences between ethnicities (Hispanics, African Americans and non-Hispanic whites) and breast cancer risk and focused on premenopausal breast cancer risk only. Here, the risk for ER/PR positive breast cancer was inversely associated with higher BMI in all three ethnic groups (BMI $\geq 30 \mathrm{~kg} / \mathrm{m}^{2}$ vs. $\leq 25 \mathrm{~kg} / \mathrm{m}^{2}$ : $\mathrm{OR}=0.42$; $95 \% \mathrm{Cl}$ 0.29-0.61), while the risk for $E R / P R$ negative breast cancer was not reduced with higher $\mathrm{BMI}(\mathrm{OR}=1.05 ; 95 \% \mathrm{Cl}$ 0.67-1.64). Another population-based case-control study reported results of the association between BMI and ER/PR positive and ER/PR negative tumors among African American and white women. The authors found an inverse not significant association between increased $\mathrm{BMI}$ and breast cancer risk in premenopausal African American and white women for both ER/PR positive and for ER/PR negative subtype [18]. Similar results were obtained by Bandera et al. [19], who evaluated the impact of body size, body fat distribution, and body composition on breast cancer risk among African American women in a case-control study and found that BMI was not significantly associated with breast cancer risk for both ER/PR positive and ER/PR negative breast cancer.

One hospital-based case-control study with 389 premenopausal breast cancer cases from Japan reported that women with higher BMI showed a decreased risk for both ER/PR positive and $E R / P R$ negative breast cancer, but the results were not statistically significant and the number of obese cases was small [20]. Wang et al. [21] conducted a case-control study with 828 premenopausal breast cancer cases from China. Among women with a BMI $\geq 28 \mathrm{~kg} / \mathrm{m}^{2}$ compared to women with a BMI $\leq 24 \mathrm{~kg} / \mathrm{m}^{2}$, both the risk for ER/PR positive breast cancer (OR 2.21; 95\% Cl 1.52-3.21) and the risk for ER/PR negative breast cancer (OR 2.05; $95 \% \mathrm{CI}$ 1.18-3.56) were positively associated with higher BMI.

A cohort study with 413 premenopausal breast cancer cases from the Sister Study [22] found that women with a BMI $\geq 35 \mathrm{~kg} / \mathrm{m}^{2}$ were less often diagnosed with ER/PR positive breast cancer (HR 0.35; 95\% Cl 0.17-0.74) compared to women with a BMI of 18.5 to $24.9 \mathrm{~kg} / \mathrm{m}^{2}$. Due to a small sample size, the study was not able to examine associations between premenopausal ER/PR negative breast cancer risk and obesity. Similar results were reported by Fagherazzi et al. [23]. In their cohort study with 277 premenopausal breast cancer cases a decreased risk for ER/ $\mathrm{PR}$ positive breast cancer was observed in women with a BMI $>30 \mathrm{~kg} / \mathrm{m}^{2}$ as compared to women with a BMI $<20 \mathrm{~kg} / \mathrm{m}^{2}(\mathrm{HR}$ 
- Table 1 Study characteristics of papers included in the systematic review.

\begin{tabular}{|c|c|c|c|c|c|c|c|c|}
\hline $\begin{array}{l}\text { First author, } \\
\text { year (Refer- } \\
\text { ence No.) }\end{array}$ & Study type & Country & Age range & $\begin{array}{l}\text { Period of } \\
\text { enrolment }\end{array}$ & $\begin{array}{l}\text { No. of } \\
\text { cases }\end{array}$ & $\begin{array}{l}\text { Immuno- } \\
\text { histo- } \\
\text { chemical } \\
\text { markers }\end{array}$ & $\begin{array}{l}\text { BMI } \\
\text { measure- } \\
\text { ment }\end{array}$ & $\begin{array}{l}\text { Anthropo- } \\
\text { metric } \\
\text { measure- } \\
\text { ments }\end{array}$ \\
\hline $\begin{array}{l}\text { John EM, } 2011 \\
\text { [17] }\end{array}$ & Case-control & $\begin{array}{l}\text { USA (San Francisco } \\
\text { Bay Area Breast } \\
\text { Cancer study) }\end{array}$ & $35-79$ & 1995-2004 & 672 & ER, PR & $\begin{array}{l}\text { Self- } \\
\text { reported }\end{array}$ & $\begin{array}{l}\text { BMI, WHR, } \\
\text { WC, HC }\end{array}$ \\
\hline $\begin{array}{l}\text { Berstad P, } \\
2010[18]\end{array}$ & Case-control & $\begin{array}{l}\text { USA (Woman Contra- } \\
\text { ceptive and Repro- } \\
\text { ductive Experiences } \\
\text { Study [CARE]) }\end{array}$ & $35-64$ & 1994-1998 & 2097 & ER, PR & $\begin{array}{l}\text { Self- } \\
\text { reported }\end{array}$ & BMI \\
\hline $\begin{array}{l}\text { Bandera EV, } \\
2013 \text { [19] }\end{array}$ & Case-control & $\begin{array}{l}\text { USA (Woman's Circle } \\
\text { of Health Study) }\end{array}$ & $20-75$ & $2002-2008$ & 469 & ER, PR & $\begin{array}{l}\text { Trained } \\
\text { personnel }\end{array}$ & $\begin{array}{l}\text { BMI, WHR, } \\
\text { WC, HC }\end{array}$ \\
\hline $\begin{array}{l}\text { Kawai M, } 2013 \\
{[20]}\end{array}$ & Case-control & Japan & $\begin{array}{l}\text { Mean } 56.8(\mathrm{ER}+/ \mathrm{PR}+) \text {, } \\
58.6(\mathrm{ER}+/ \mathrm{PR}-) \\
56.8(\mathrm{ER}-/ \mathrm{PR}-)\end{array}$ & 1997-2009 & 389 & ER, PR & $\begin{array}{l}\text { Self- } \\
\text { reported }\end{array}$ & BMI \\
\hline $\begin{array}{l}\text { Wang F, } 2017 \\
{[21]}\end{array}$ & Case-control & China & $25-70$ & 2012-2013 & 828 & ER, PR & $\begin{array}{l}\text { Self- } \\
\text { reported }\end{array}$ & $\begin{array}{l}\text { BMI, WC, } \\
\text { HC, WHR }\end{array}$ \\
\hline $\begin{array}{l}\text { White A], } 2015 \\
\text { [22] }\end{array}$ & Cohort & Sister Study, USA & $35-74$ & 2003-2009 & 413 & ER, PR & $\begin{array}{l}\text { Trained } \\
\text { personnel }\end{array}$ & $\begin{array}{l}\text { BMI, WC, } \\
\text { WHR }\end{array}$ \\
\hline $\begin{array}{l}\text { Fagherazzi G, } \\
2012 \text { [23] }\end{array}$ & Cohort & France (E3N) & $40-65$ & 1990-1991 & 277 & ER, PR & $\begin{array}{l}\text { Self- } \\
\text { reported }\end{array}$ & $\begin{array}{l}\text { BMI, WC, } \\
\text { HC, WHR, }\end{array}$ \\
\hline $\begin{array}{l}\text { Nagrani R, } \\
2016 \text { [24] }\end{array}$ & Case-control & India & $20-69$ & $2009-2013$ & 818 & ER, PR, HER2 & $\begin{array}{l}\text { Self- } \\
\text { reported }\end{array}$ & $\begin{array}{l}\text { BMI, WHR, } \\
\text { WC }\end{array}$ \\
\hline $\begin{array}{l}\text { Sahin S, } 2017 \\
\text { [25] }\end{array}$ & Single cohort & Turkey & Median 48.6 & 1994-2015 & 1834 & ER, PR, HER2 & Unknown & BMI \\
\hline $\begin{array}{l}\text { Biglia N, } 2012 \\
\text { [11] }\end{array}$ & Single cohort & Italy & Mean 45 & 1999-2009 & 592 & $\begin{array}{l}\text { ER, PR, HER2, } \\
\text { Ki67 }\end{array}$ & Unknown & BMI \\
\hline $\begin{array}{l}\text { Yanai A, } 2014 \\
\text { [13] }\end{array}$ & Single cohort & Japan & Mean 44.5 & 2005-2012 & 187 & $\begin{array}{l}\text { ER, PR, HER2, } \\
\text { Ki67 }\end{array}$ & Unknown & BMI \\
\hline $\begin{array}{l}\text { Nattenmüller } \\
\text { C], } 2018 \text { [26] }\end{array}$ & Cohort & $\begin{array}{l}\text { Germany (EPIC- } \\
\text { Germany-study) }\end{array}$ & $35.2-65.2$ & 1994-2010 & 308 & $\begin{array}{l}\text { ER, PR, HER2, } \\
\text { Ki67, Bcl-2, } \\
\text { p53 }\end{array}$ & $\begin{array}{l}\text { Trained } \\
\text { personnel }\end{array}$ & BMI \\
\hline $\begin{array}{l}\text { Yang XR, } 2007 \\
{[27]}\end{array}$ & Case-control & Poland & $20-74$ & $2000-2003$ & 217 & $\begin{array}{l}\text { ER, PR, HER2, } \\
\text { HER1, CK5 }\end{array}$ & $\begin{array}{l}\text { Self- } \\
\text { reported }\end{array}$ & BMI \\
\hline $\begin{array}{l}\text { Chen FY, } 2013 \\
\text { [28] }\end{array}$ & Single cohort & China & $\begin{array}{l}\text { Median } 54.1 \text { (obese), } \\
45.1 \text { (underweight) }\end{array}$ & 2001-2011 & 1277 & $\begin{array}{l}\text { ER, PR, HER2, } \\
\text { Ki67 }\end{array}$ & Unknown & BMI \\
\hline $\begin{array}{l}\text { Chen L, } 2016 \\
\text { [29] }\end{array}$ & Single cohort & $\begin{array}{l}\text { USA (Seattle-Puget } \\
\text { Sound, Washington) }\end{array}$ & $20-69$ & 2004-2012 & 1217 & ER, PR, HER2 & $\begin{array}{l}\text { Self- } \\
\text { reported, } \\
\text { medical } \\
\text { records }\end{array}$ & BMI \\
\hline $\begin{array}{l}\text { Milikan RC, } \\
2008[30]\end{array}$ & Case-control & $\begin{array}{l}\text { USA (Carolina Breast } \\
\text { Cancer Study [CBCS]) }\end{array}$ & $20-74$ & 1993-2001 & 638 & ER, PR, HER2 & $\begin{array}{l}\text { Trained } \\
\text { personnel }\end{array}$ & BMI \\
\hline $\begin{array}{l}\text { Agresti R, } 2016 \\
\text { [31] }\end{array}$ & $\begin{array}{l}\text { Cross- } \\
\text { sectional }\end{array}$ & Italy & Median age 45.2 & 2011-2015 & 596 & $\begin{array}{l}\text { ER, PR, HER2, } \\
\text { Ki67 }\end{array}$ & Unknown & BMI, WC \\
\hline $\begin{array}{l}\text { Lara-Medina F, } \\
2011 \text { [32] }\end{array}$ & Single cohort & Mexico & Mean age 50 & 1998-2008 & 269 & ER, PR, HER2 & $\begin{array}{l}\text { Self- } \\
\text { reported }\end{array}$ & BMI \\
\hline $\begin{array}{l}\text { Lin NU, } 2012 \\
\text { [33] }\end{array}$ & Single cohort & USA & Mean age 55 & 2000-2006 & 6175 & ER, PR, HER2 & $\begin{array}{l}\text { Self- } \\
\text { reported }\end{array}$ & BMI \\
\hline Li H, 2017 [34] & Case-control & China & $\begin{array}{l}\text { Mean } 47.73 \text { (lumi- } \\
\text { nal), } 48.62 \text { (HER2+), } \\
49.54 \text { (TNBC) }\end{array}$ & $2002-2010$ & 739 & ER, PR, HER2 & Unknown & BMI \\
\hline $\begin{array}{l}\text { Yang XR, } 2011 \\
\text { [35] }\end{array}$ & $\begin{array}{l}\text { Pooled } \\
\text { analysis }\end{array}$ & $\begin{array}{l}\text { Different countries } \\
\text { (mostly Europe) }\end{array}$ & Median age 55.3 & 1992-2009 & 55580 & $\begin{array}{l}\text { ER, PR, HER2, } \\
\text { CK5 }\end{array}$ & Unknown & BMI \\
\hline
\end{tabular}


0.40; 95\% Cl 0.16-1.00), while there was no association between increased $\mathrm{BMI}$ and ER/PR negative breast cancer risk.

One single cohort study focused on Indian women's breast cancer risk, according to TNBC subtype, ER/PR statuses and obesity-related anthropometric measurements, like WHR, WC and BMI [24]. Their results regarding BMI and breast cancer risk did not vary by hormone receptor status; a BMI $\geq 30 \mathrm{~kg} / \mathrm{m}^{2}$ compared with normal BMI was associated with a decreased risk for both ER/ PR positive (OR 0.43; $95 \% \mathrm{Cl} 0.25-0.73$ ) and ER/PR negative (OR 0.55 ; $95 \% \mathrm{Cl} 0.34-0.89$ ) breast cancer. A study from Turkey reported significantly more ER positive tumors in premenopausal patients with a BMI $\leq 25 \mathrm{~kg} / \mathrm{m}^{2}$ compared to women with a BMI $\geq 25 \mathrm{~kg} / \mathrm{m}^{2}$, and patients with BMI $\geq 30 \mathrm{~kg} / \mathrm{m}^{2}$ had significantly more ER/PR negative tumors compared to those with BMI $\leq 25 \mathrm{~kg} / \mathrm{m}^{2}$ [25]. An Italian single cohort study reported only information on ER/PR positive tumors in premenopausal women but no statistically significant associations between the risk for hormone receptor positive tumors and BMI were found [31].

The pooled analysis from the breast cancer association consortium studies by Yang XR et al. [35] found out that obesity in younger women ( $<50$ years) was more frequent in ER/PR negative compared to ER/PR positive tumors (OR 1.49; 95\% Cl 1.29-1.73).

\section{Luminal subtypes and breast cancer risk}

Nine studies included, of which three were case-control studies, reported data on luminal subtypes in premenopausal women. It should be noted that from the nine studies, two of the studies defined the luminal B subtype as HER2 negative, whereas the other studies used the luminal B definition irrespectively to HER2 status. This restricts the data interpretation. From the case-control studies evaluating the risk of luminal BC in obese patients, two of them reported a decreased risk for luminal A or B cancers [27, $30]$, whereas one showed an increased risk for luminal A cancer [34]. The cohort and cross-sectional studies included found no significant association between obesity and the risk of luminal tumor subtype [13, 25, 26, 28, 29, 31].

The most recently published study included in this review was a prospective cohort study from Germany by Nattenmüller et al. [26]. They hypothesized that obese women, regardless from menopausal status, have less aggressive tumors than women with underweight or normal weight. Their results show that there were no significant associations between BMI and the risk of any tumor subtype as defined by a single marker in premenopausal women, but women in the highest BMI tertile showed a significantly lower risk for less aggressive tumors (i.e. ER+, PR+, HER2-, Ki67 low) compared to women in the lowest BMI tertile (HR 0.55; $95 \% \mathrm{Cl}$ 0.33-0.93).

A population-based case-control study by Yang et al. [27] evaluated breast cancer risk according to BMI and subtype in 217 premenopausal breast cancer cases from Poland. Increased BMI reduced the risk for luminal $A(O R 0.71 ; 95 \% \mathrm{Cl} 0.57-0.88)$ and luminal B (OR 0.88; $95 \% \mathrm{Cl} 0.48-1.60)$ subtypes. Another population-based case-control study investigated effects of obesity on risk for different breast cancer subtypes in East Asian women. They observed a positive association between higher BMI $\left(\geq 25 \mathrm{~kg} / \mathrm{m}^{2}\right.$ ) and luminal subtypes (OR 1.88; 95\% Cl 1.31-2.69) [34]. Chen F et al. [28] reported in their single cohort study from
China that luminal A and B tumor subtypes tended to be observed more often in normal weight and underweight women compared to overweight and obese women, but the findings were not significant. Breast cancer patients from Turkey were retrospectively analyzed for associations between BMI and breast cancer subtypes. Patients with $\mathrm{BMI} \geq 30 \mathrm{~kg} / \mathrm{m}^{2}$ were less often diagnosed with a luminal subtype compared to women with $\mathrm{BMl} \leq 25 \mathrm{~kg} / \mathrm{m}^{2}$ [25]. Another single cohort study with 1217 premenopausal breast cancer cases found no significant association between the diagnosis of luminal subtypes and BMI in premenopausal women [29]. Data from the CBCS case-control study reported a significantly decreased risk for overweight and obese women for breast cancer of the luminal A subtype (OR 0.7; 95\% CI 0.5-1.0) [30]. No significant associations between BMI and luminal subtypes were found in a single cohort study from Japan by Yanai et al. and in a crosssectional study from Italy $[13,31]$.

\section{TNBC subtype and premenopausal breast cancer risk}

Twelve of the analyzed studies reported data on TNBC cases in premenopausal women, including three case-control studies. Two of these three studies showed a significantly increased risk for TNBC in obese patients [30,34] and one found no significant association [24].

A single cohort study focused on TNBC cases among Hispanic women and showed that TNBC prevalence was not significantly associated with $\mathrm{BMI} \geq 25 \mathrm{~kg} / \mathrm{m}^{2}$ or BMl $\geq 30 \mathrm{~kg} / \mathrm{m}^{2}$ in premenopausal women [32]. In contrast, Chen L et al. [29] showed that a $\mathrm{BMI} \geq 30 \mathrm{~kg} / \mathrm{m}^{2}$ was significantly associated with TNBC risk in premenopausal American women (OR 1.82; 95\% Cl 1.32-2.51).

A case-control study reported by Lin et al. [33] reported an increased risk for TNBC subtype in obese Polish women. The triple negative tumors were related to the highest BMI categories but the results were not significant (OR 1.18; 95\% Cl 0.86-1.64 per five unit increase) In contrast, Li et al. [34] found that BMI $\geq 25 \mathrm{~kg} / \mathrm{m}^{2}$ was associated with elevated risk for TNBC (OR 2.51, $95 \% \mathrm{Cl} 1.53-4.12)$.

TNBC cases were significantly higher in overweight (OR 2.8; 95\% Cl 1.3-6.1) and obese (OR 3.7; 95\% Cl 1.2-12.1) premenopausal Chinese women when compared to the luminal A subtype, and a cross-sectional study from Italy obtained the same results for women with BMI $\geq 25 \mathrm{~kg} / \mathrm{m}^{2}$ (OR 3.04; 95\% Cl 1.43-6.43) $[28,31]$. In a Turkish population, the TNBC subtype was also significantly more frequent in premenopausal patients with BMI $\geq 30 \mathrm{~kg} / \mathrm{m}^{2}$ compared to $\mathrm{BMI} \leq 30 \mathrm{~kg} / \mathrm{m}^{2}$ [25]. A retrospective analysis of breast cancer cases from the National Comprehensive Cancer Network of the United States showed that among obese premenopausal women $24 \%$ of breast cancers were triple-negative compared with $16 \%$ of normal-weight premenopausal women [36]. In contrast, there were no significant differences between $\mathrm{BMI}$ groups with regard to TNBC subtype frequencies in a study from India [24]. A population-based, case-control study of African-American and white women showed that TNBC subtype was more frequent in overweight (OR 1.7; 95\% Cl 1.0-3.1) and obese (OR 1.6; 95\% Cl 0.9-2.7) premenopausal women compared to women with a BMI $<25 \mathrm{~kg} / \mathrm{m}^{2}$ [30]. No statistically significant association between BMI and TNBC was detected by Yanai et al. in patients from Japan [13]. 
- Table 2 Breast cancer subtype risk in premenopausal obese women, as reported in case-control studies.

\begin{tabular}{|l|l|l|l|}
\hline BC subtype & $\begin{array}{l}\text { Number of case-control studies } \\
\text { showing an increased risk }\end{array}$ & $\begin{array}{l}\text { Number of case-control studies } \\
\text { showing a decreased risk }\end{array}$ & $\begin{array}{l}\text { Number of case-control studies } \\
\text { showing no association }\end{array}$ \\
\hline ER/PR+ & 1 & 2 & 3 \\
\hline ER/PR- & 1 & 1 & 4 \\
\hline Luminal A & 1 & 2 & 0 \\
\hline Luminal B & 0 & 2 & 0 \\
\hline TNBC & 2 & 0 & 1 \\
\hline HER2 positive & 0 & 0 & 2 \\
\hline
\end{tabular}

The pooled analysis by Yang XR et al. [35] reported a significantly higher risk for obesity among younger women ( $<50$ years) and TNBC compared to women with BMI <25 (OR 1.8; $95 \% \mathrm{Cl}$ $1.42-2.29)$ [35].

\section{HER2-positive subtype and premenopausal breast cancer risk}

Only six studies with a limited number of cases analyzed the relationship between BMI and risk for ER/PR positive and HER2-positive breast cancer subtypes among premenopausal women [25, $29-31,34]$. Results of the four cohort studies and from two case-control studies found not significant risk for HER2-positive subtype among obese women [34], but one study reported a significantly higher risk in the subgroup of overweight women [30].

Li et al. [34] found not significantly higher risks for patients with $\mathrm{BMI} \geq 25 \mathrm{~kg} / \mathrm{m}^{2}$ (OR 2.25, 95\% Cl 0.82-6.17). Millikan et al. [30] showed that BMI tended to decrease risk for HER2-positive subtype among obese women (OR 0.6; 95\% Cl 0.3-1.5) but not in overweight women (OR 1.1; 95\% Cl 0.5-2.3). Chen $\mathrm{L}$ et al. [29] reported in premenopausal overweight and obese patients a higher frequency of the HER2-positive subtype, but the risk was not increased significantly (OR 1.24; 95\% Cl 0.81-1.88 and OR 1.41 ; $95 \% \mathrm{Cl} 0.92-2.16$ for overweight and obese women, respectively).

- Table 2 summarizes the frequency of particular findings from the case-control studies included in this review. As observed, the amount of the evidence is low and uncertain whether obesity is a risk factor for different BC subtypes in this group of patients.

\section{Risk of bias within studies}

There are potential risks of bias within the studies. The definition for overweight and obesity varied between different countries and were not all classified according to the WHO criteria. Measurements of BMI were either self-reported or measured standardized by trained staff, or the type of anthropometric measurements was not described. Another risk of bias is the various use of definitions on subtypes, especially luminal B tumors are often classified as either HER2 negative or subdivided into HER2 positive or negative.

The biggest risks of bias are the small sample sizes regarding severely obese women and TNBC and HER2 positive women. In addition, many of the reported associations provide from studies that were not designed to estimate the differences between all intrinsic BC subtypes.

\section{Discussion}

Obesity in premenopausal women has been associated with an increase in mortality rate $[8,10]$; however, the relationship between obesity and the different premenopausal breast cancer intrinsic subtypes is not completely elucidated. This review, comprising a total of 55580 breast cancer patients from six case-studies and 15 observational studies regarding obesity as a risk factor for specific breast cancer subtypes in premenopausal women, indicated that a higher BMI might influence aggressive tumor characteristics among premenopausal women. In addition, heterogeneous risks for different breast cancer subtypes among obese premenopausal women were found, suggesting that obesity could have divergent impacts on the risk of different breast cancer subtypes.

Among studies regarding to ER/PR statuses and obesity in premenopausal women with breast cancer, six studies reported reduced risk for hormone receptor positive breast cancer in premenopausal women with a high BMI, whereas 4 studies reported non-significant results for increased risk of obese premenopausal women and ER/PR positive breast cancer. One study reported a significant association in hormone receptor positive breast cancer risk and increased BMI. ER/PR negative breast cancer risk in obese women was decreased in one of the studies, but three studies reported an increased risk for ER/PR negative breast cancer. Six studies evaluated no association for hormone receptor negative tumors and obesity in premenopausal women, whereas one study was not able to report results, due to a small sample size.

A meta-analysis by Munsell et al. reported that obesity in premenopausal women was associated with a $20 \%$ reduction in ER/PR positive breast cancer incidence, while no such association was observed for ER/PR negative premenopausal breast cancer [7]. Another meta-analysis also reported a $20 \%$ lower risk for hormone receptor positive breast cancer among premenopausal obese women, and each 5-unit increase in BMl was associated with a $10 \%$ decreased risk for ER/PR positive breast cancer. Similar to the results of the meta-analysis by Munsell et al., a meta-analysis by Suzuki $R$ et al. observed no associations with regard to the risk for ER/PR negative tumors [37]. However, the pooled analysis by Yang XR et al. [35] reported a higher risk association for ER/PR negative tumors in obese younger women but the results for ER/ 


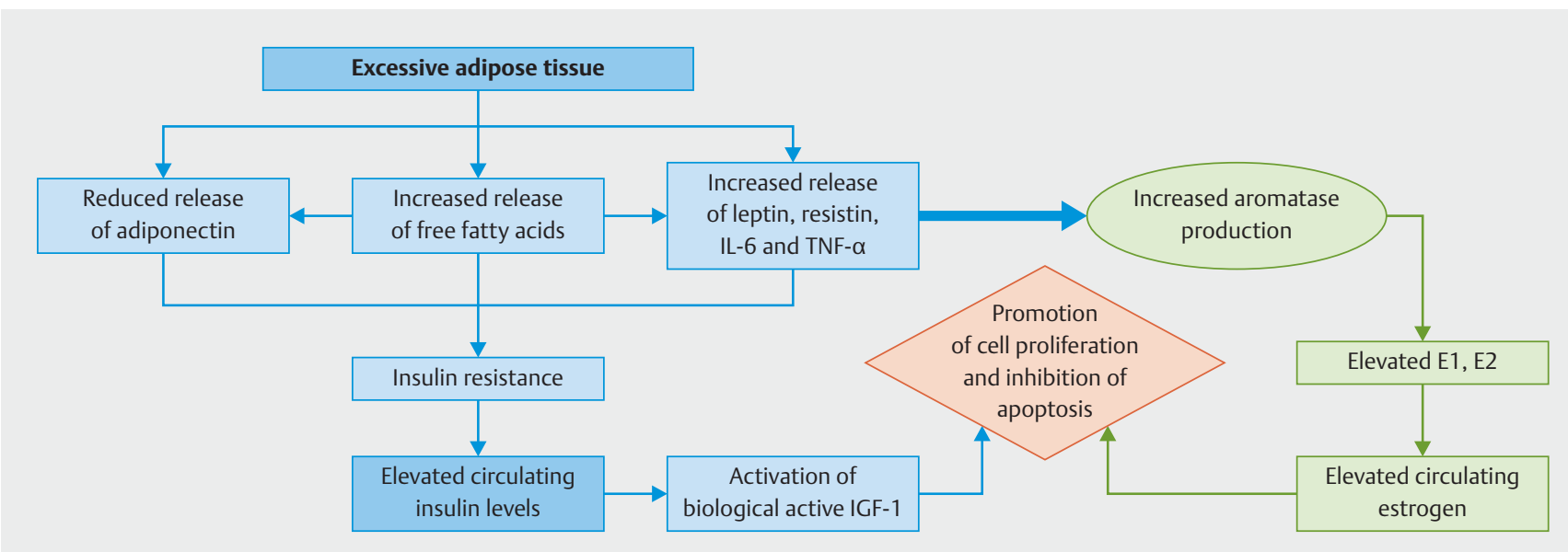

- Fig. 2 Possible effects of obesity on breast cancer in premenopausal women. Own design.

PR positive tumors were conformable with the results described above. A recently published pooled analysis by the premenopausal breast cancer collaborative group also reported inverse associations between BMI and ER/PR positive breast cancer risk in premenopausal women at every age [38]. The results of the current review with regard to $E R / P R$ positive and $E R / P R$ negative tumors are concordant with the results of the meta-analyses and the pooled analysis mentioned above.

In regard to the associations of BMI with the risk for luminal $A$ and $B$ breast cancer subtypes in premenopausal women, three studies observed decreased risk for luminal-A subtype; whereas six studies reported no statistically significant relations between luminal-A subtypes and obesity in premenopausal women and six studies found no statistically significant relations for luminal-B subtype in this population, while one reported a decreased risk for this population.

TNBC tends to be more frequent in obese and severe obese premenopausal women. Seven of the 12 analyzed studies reported positive and significant associations for premenopausal TNBC risk and obesity, while the remaining five studies reported no associations or no significant results. A review and meta-analysis reported by Pierobon et al. [36] is in accordance with these findings, suggesting that obese premenopausal women with a BMI $\geq 30 \mathrm{~m}^{2}$ have a $42 \%$ higher risk of developing TNBCC. The pooled analysis by Yang XR et al. [35] also reported a significantly higher risk for younger obese women and TNBC. In contrast to these results, the pooled analysis by the premenopausal breast cancer collaborative group reported no association between increased BMI at 25 years or older and TNBC.

In postmenopausal women adipose tissue is the main site of estrogen production. The increase in risk for hormone receptor positive cancer might be explained by higher rates of circulating E1 and E2 through the increased aromatase enzyme activity in adipose tissue [39]. Increased levels of E1, E2 and free estradiol are associated with increased BMI, but only in postmenopausal women [40]. In contrast, premenopausal women mainly synthesize estrogens in the ovaries and obese women have a higher prevalence of irregular and less frequent or anovulatory cycles, re- sulting in decreased E2 and progesterone levels [41]. This mechanism could explain the decreased risk for hormone-receptor positive breast cancer in obese premenopausal women and the higher risk for TNBC in obese premenopausal women. A pooled analysis from the Endogenous Hormones and Breast Cancer Collaborative Group reported decreased levels of total E2 and progesterone in obese premenopausal women, but increased levels of free E2, dehydroepiandrosterone sulphate (DHEAS), and T, which contradicts the hypothesis before [42].

Obesity is also associated with inflammation, hyperinsulinemia, insulin resistance and elevated levels of insulin and insulinlike growth factor 1 (IGF-1) [9]. The release of free fatty acids and peptide hormones, such as leptin, interleukin-6 (IL-6) TNF- $\alpha$, and the reduced release of adiponectin lead to insulin resistance and compensatory hyperinsulinemia. In turn, the synthesis of IGF-1 is promoted, which induces cell proliferation and inhibits apoptosis. These mechanisms could explain the higher aggressiveness of premenopausal breast cancer in obese women ( $\vee$ Fig. 2 ).

Nulliparity, increasing age at first full term birth and early age at menarche are reported to be associated with the risk of ER/PR positive tumors but not with ER/PR negative tumors [30,35]. These facts together could lead to the hypothesis that there could exist other factors beside the woman's hormonal status for hormone receptor negative tumors.

\section{Conclusion}

Based on the 21 publications considered for the present systematic analysis, it is not possible to conclude if obesity is a risk factor for specific BC subtypes in premenopausal women. However, the evidence reviewed here suggests some differences with regard to the frequency of breast cancer subtypes in relation to BMI, with younger, premenopausal obese women tending to have more aggressive tumors. More data are needed to fully understand how obesity affects the risk for different BC subtypes and how dysmetabolisms may be related to BC subtypes. 


\section{Conflict of Interest}

The authors declare that they have no conflict of interest.

\section{References}

[1] World Health Organization (WHO). Obesity - Preventing and Managing the Global Epidemic: Report of a WHO Consultation. Geneva, Switzerland: World Health Organization; 2000. Online: https://apps.who.int/ iris/handle/10665/42330; last access: 02.09.2019

[2] Renehan AG, Tyson M, Egger M et al. Body-mass index and incidence of cancer: a systematic review and meta-analysis of prospective observational studies. Lancet 2008; 371: 569-578. doi:10.1016/S0140-6736 (08)60269-X

[3] Renehan AG, Soerjomataram I, Tyson M et al. Incident cancer burden attributable to excess body mass index in 30 European countries. Int J Cancer 2010; 126: 692-702. doi:10.1002/ijc.24803

[4] Calle EE, Rodriguez C, Walker-Thurmond K et al. Overweight, obesity, and mortality from cancer in a prospectively studied cohort of U.S. adults. N Engl J Med 2013; 348: 1625-1638. doi:10.1056/NEJMoa 021423

[5] Abarca-Gómez L, Abdeen ZA, Hamid ZA et al. Worldwide trends in bodymass index, underweight, overweight and obesity from 1975 to 2016: a pooled analysis of 2416 population-based measurement studies in 128.9 children, adolescents and adults. Lancet 2017; 390: 2627-2642. doi:10.1016/S0140-6736(17)32129-3

[6] Mensink GBM, Schienkiewitz A, Haftenberger $M$ et al. Übergewicht und Adipositas in Deutschland: Ergebnisse der Studie zur Gesundheit Erwachsener in Deutschland (DEGS1). Bundesgesundheitsblatt 2013; 56: 795-801. doi:10.1007/s00103-013-1669-6

[7] Munsell MF, Sprague BL, Berry DA et al. Body mass index and breast cancer risk according to postmenopausal estrogen-progestin use and hormone receptor status. Epidemiol Rev 2014; 36: 114-136. doi:10.1093/ epirev/mxt010

[8] Berclaz G, Li S, Price KN et al. Body mass index as a prognostic feature in operable breast cancer: the International Breast Cancer Study Group experience. Ann Oncol 2004; 15: 875-884. doi:10.1093/annonc/mdh222

[9] Calle EE, Kaaks R. Overweight, obesity and cancer: epidemiological evidence and proposed mechanisms. Nat Rev Cancer 2004; 4: 579-591. doi:10.1038/nrc1408

[10] Kawai M, Minami Y, Nishino $Y$ et al. Body mass index and survival after breast cancer diagnosis in Japanese women. BMC Cancer 2012; 12 : 149. doi:10.1186/1471-2407-12-149

[11] Biglia N, Peano E, Sgandurra P et al. Body mass index (BMI) and breast cancer: impact on tumor histopathologic features, cancer subtypes and recurrence rate in pre and postmenopausal women. Gynecol Endocrinol 2013; 29: 263-267. doi:10.3109/09513590.2012.736559

[12] Daling JR, Malone KE, Doody DR et al. Relation of body mass index to tumor markers and survival among young women with invasive ductal breast carcinoma. Cancer 2001; 92: 720-729. doi:10.1002/1097-0142 (20010815)92:4<720::aid-cncr1375>3.0.co;2-t

[13] Yanai A, Miyagawa $Y$, Murase $K$ et al. Influence of body mass index on clinicopathological factors including estrogen receptor, progesterone receptor, and Ki67 expression levels in breast cancers. Int J Clin Oncol 2014; 19: 467-472. doi:10.1007/s10147-013-0585-y

[14] Viale G. The current state of breast cancer classification. Ann Oncol 2012; 23 (Suppl. 10): x207-x210. doi:10.1093/annonc/mds326

[15] Kreipe HH. Translationale Forschung und Diagnostik beim Mammakarzinom. Pathologe 2012; 33 (Suppl. 2): 282-290. doi:10.1007/s00292012-1645-1
[16] Moher D, Liberati A, Tetzlaff J et al.; PRISMA Group. Preferred reporting items for systematic reviews and meta-analyses: the PRISMA statement. BMJ 2009; 339: b2535. doi:10.1136/bmj.b2535

[17] John EM, Sangaramoorthy M, Phipps Al et al. Adult body size, hormone receptor status, and premenopausal breast cancer risk in a multiethnic population: the San Francisco Bay Area breast cancer study. Am J Epidemiol 2011; 173: 201-216. doi:10.1093/aje/kwq345

[18] Berstad P, Coates RJ, Bernstein L et al. A case-control study of body mass index and breast cancer risk in white and African-American women. Cancer Epidemiol Biomarkers Prev 2010; 19: 1532-1544. doi:10.1158/ 1055-9965.EPI-10-0025

[19] Bandera EV, Chandran U, Zirpoli G et al. Body fatness and breast cancer risk in women of African ancestry. BMC Cancer 2013; 13: 475. doi:10.1186/1471-2407-13-475

[20] Kawai M, Kakugawa Y, Nishino Y et al. Anthropometric factors, physical activity, and breast cancer risk in relation to hormone receptor and menopausal status in Japanese women: a case-control study. Cancer Causes Control 2013; 24: 1033-1044. doi:10.1007/s10552-013-0181-5

[21] Wang F, Liu L, Cui S et al. Distinct Effects of Body Mass Index and Waist/ Hip Ratio on Risk of Breast Cancer by Joint Estrogen and Progestogen Receptor Status: Results from a Case-Control Study in Northern and Eastern China and Implications for Chemoprevention. Oncologist 2017; 22: 1431-1443. doi:10.1634/theoncologist.2017-0148

[22] White AJ, Nichols HB, Bradshaw PT et al. Overall and central adiposity and breast cancer risk in the Sister Study. Cancer 2015; 121: 37003708. doi:10.1002/cncr.29552

[23] Fagherazzi G, Chabbert-Buffet N, Fabre A et al. Hip circumference is associated with the risk of premenopausal ER-/PR- breast cancer. Int J Obes 2012; 36: 431-439. doi:10.1038/ijo.2011.66

[24] Nagrani R, Mhatre S, Rajaraman P et al. Central obesity increases risk of breast cancer irrespective of menopausal and hormonal receptor status in women of South Asian Ethnicity. Eur J Cancer 2016; 66: 153-161. doi:10.1016/j.ejca.2016.07.022

[25] Sahin S, Erdem GU, Karatas F et al. The association between body mass index and immunohistochemical subtypes in breast cancer. Breast 2017; 32: 227-236. doi:10.1016/j.breast.2016.09.019

[26] Nattenmüller C], Kriegsmann M, Sookthai D et al. Obesity as risk factor for subtypes of breast cancer: results from a prospective cohort study. BMC Cancer 2018; 18: 616. doi:10.1186/s12885-018-4548-6

[27] Yang XR, Sherman ME, Rimm DL et al. Differences in risk factors for breast cancer molecular subtypes in a population-based study. Cancer Epidemiol Biomarkers Prev 2007; 16: 439-443. doi:10.1158/10559965.EPI-06-0806

[28] Chen FY, Ou HY, Wang SM et al. Associations between body mass index and molecular subtypes as well as other clinical characteristics of breast cancer in Chinese women. Ther Clin Risk Manag 2013; 9: 131-137. doi:10.2147/TCRM.S41203

[29] Chen L, Cook LS, Tang M-TC et al. Body mass index and risk of luminal, HER2-overexpressing, and triple negative breast cancer. Breast Cancer Res Treat 2016; 157: 545-554. doi:10.1007/s10549-016-3825-9

[30] Millikan RC, Newman B, Tse CK et al. Epidemiology of basal-like breast cancer. Breast Cancer Res Treat 2008; 109: 123-139. doi:10.1007/ s10549-007-9632-6

[31] Agresti R, Meneghini E, Baili P et al. Association of adiposity, dysmetabolisms, and inflammation with aggressive breast cancer subtypes: a cross-sectional study. Breast Cancer Res Treat 2016; 157: 179-189. doi:10.1007/s10549-016-3802-3

[32] Lara-Medina F, Pérez-Sánchez V, Saavedra-Pérez D et al. Triple-negative breast cancer in Hispanic patients: high prevalence, poor prognosis, and association with menopausal status, body mass index, and parity. Cancer 2011; 117: 3658-3669. doi:10.1002/cncr.25961 
[33] Lin NU, Vanderplas A, Hughes ME et al. Clinicopathologic features, patterns of recurrence, and survival among women with triple-negative breast cancer in the National Comprehensive Cancer Network. Cancer 2012; 118: 5463-5472. doi:10.1002/cncr.27581

[34] Li H, Sun X, Miller E et al. BMI, reproductive factors, and breast cancer molecular subtypes: A case-control study and meta-analysis. J Epidemiol 2017; 27: 143-151. doi:10.1016/j.je.2016.05.002

[35] Yang XR, Chang-Claude J, Goode EL et al. Associations of breast cancer risk factors with tumor subtypes: a pooled analysis from the Breast Cancer Association Consortium studies. J Natl Cancer Inst 2011; 103: 250263. doi:10.1093/jnci/djq526

[36] Pierobon M, Frankenfeld CL. Obesity as a risk factor for triple-negative breast cancers: a systematic review and meta-analysis. Breast Cancer Res Treat 2013; 137: 307-314. doi:10.1007/s10549-012-2339-3

[37] Suzuki R, Orsini N, Saji S et al. Body weight and incidence of breast cancer defined by estrogen and progesterone receptor status-a meta-analysis. Int J Cancer 2009; 124: 698-712. doi:10.1002/ijc.23943
[38] Schoemaker M], Nichols HB, Wright LB et al.; Premenopausal Breast Cancer Collaborative Group. Association of Body Mass Index and Age With Subsequent Breast Cancer Risk in Premenopausal Women. JAMA Oncol 2018; 4: e181771. doi:10.1001/jamaoncol.2018.1771

[39] McTiernan A, Rajan KB, Tworoger SS et al. Adiposity and sex hormones in postmenopausal breast cancer survivors. J Clin Oncol 2003; 21: 1961 1966. doi:10.1200/JCO.2003.07.057

[40] Cleary MP, Grossmann ME. Minireview: Obesity and breast cancer: the estrogen connection. Endocrinology 2009; 150: 2537-2542. doi:10.1210/en.2009-0070

[41] Key TJ, Pike MC. The role of oestrogens and progestagens in the epidemiology and prevention of breast cancer. Eur J Cancer Clin Oncol 1988; 24: 29-43

[42] Key T], Appleby PN, Reeves GK et al. Sex hormones and risk of breast cancer in premenopausal women: a collaborative reanalysis of individual participant data from seven prospective studies. Lancet Oncol 2013; 14: 1009-1019. doi:10.1016/S1470-2045(13)70301-2 